\title{
The motor skills and sensory processing abilities associated with idiopathic toe walking gait
}

\author{
Cylie Williams ${ }^{1,2^{*}}$, Paul Tinley ${ }^{3}$, Michael Curtin ${ }^{4}$, Sharon Nielsen ${ }^{5}$ \\ From Australasian Podiatry Council Conference 2013 \\ Sydney, Australia. 2-5 June 2013
}

\section{Background}

This study aimed to investigate differences between the motor skills and sensory processing abilities of children between the ages of four and eight years with and without an idiopathic toe walking (ITW) gait.

\section{Methods}

Children in each cohort were tested with the following norm referenced assessments:

1. Bruininks-Oseretsky Test of Motor Proficiency 2nd edition (BOT-2)

2. The Sensory Profile (SP)

3. Six subtests of the Sensory Integration and Praxis Tests (SIPT)

4. Vibration Perception Threshold (VPT)

\section{Results}

Sixty children participated in the study, 30 within each cohort. Those with an ITW gait were found to have different SP quadrant scores $(\mathrm{p}=0.002)$, poorer performance on the BOT-2 $(\mathrm{p}=<.001)$, a lower VPT $(\mathrm{p}=.001)$ and poorer performance on the Standing Walking Balance subtest of the SIPT $(\mathrm{p}=0.047)$ compared with peers.

\section{Conclusion}

While the results did not identify a causative factor for an ITW gait, they do suggest that the toe walking gait may not be idiopathic in nature. The results of this research highlight the importance of a fuller assessment of the toe walking child compared to that traditionally conducted by podiatrists, and suggest that multiple strategies may be required to manage this gait style.

\footnotetext{
*Correspondence: cylie.williams@southernhealth.org.au

'Allied Health Research Unit, Southern Health, Cheltenham, VIC, 3192,

Australia

Full list of author information is available at the end of the article
}

\begin{abstract}
Author details
'Allied Health Research Unit, Southern Health, Cheltenham, VIC, 3192, Australia. ${ }^{2}$ Department of Physiotherapy, Monash University, Frankston, VIC, 3199, Australia. ${ }^{3}$ School of Podiatry, Charles Sturt University, Albury, NSW, 2460, Australia. ${ }^{4}$ School of Occupational Therapy, Charles Sturt University, Albury, NSW, 2460, Australia. ${ }^{5}$ Quantitative Consulting Unit, Charles Sturt University, Wagga Wagga, NSW, 2678, Australia.
\end{abstract}

Published: 31 May 2013

doi:10.1186/1757-1146-6-S1-038

Cite this article as: Williams et al:: The motor skills and sensory

processing abilities associated with idiopathic toe walking gait. Journal of Foot and Ankle Research 2013 6(Suppl 1):O38.
Submit your next manuscript to BioMed Central and take full advantage of:

- Convenient online submission

- Thorough peer review

- No space constraints or color figure charges

- Immediate publication on acceptance

- Inclusion in PubMed, CAS, Scopus and Google Scholar

- Research which is freely available for redistribution

Submit your manuscript at www.biomedcentral.com/submit
C Biomed Central 